\title{
Implementing the millennium development food security goals - Challenges of the southern African context
}

\author{
David Love ${ }^{\mathrm{a}, \mathrm{b}, \mathrm{d}, *}$, Steve Twomlow ${ }^{\mathrm{b}}$, Walter Mupangwa ${ }^{\mathrm{b}}$, \\ Pieter van der Zaag ${ }^{c}$, Bekithemba Gumbo ${ }^{\mathrm{a}}$ \\ ${ }^{a}$ WaterNet, PO Box MP600, Mount Pleasant, Harare, Zimbabwe \\ ${ }^{\mathrm{b}}$ ICRISAT Bulawayo, Matopos Research Station, PO Box 776, Bulawayo, Zimbabwe \\ ${ }^{\mathrm{c}}$ UNESCO-IHE, PO Box 3015, 2601 DA Delft, The Netherlands \\ ${ }^{\mathrm{d}}$ Water Resources Section, Delft University of Technology, Delft, The Netherlands
}

\begin{abstract}
The Millennium Development Goals' target to halve the proportion of people who suffer from hunger is extremely important in southern Africa, where food security has become increasingly problematic over the last 20 years. One "quick-win" proposal is replenishment of soil nutrients for smallholder farmers, through free or subsidised chemical fertilisers. Other proposals include appropriate irrigation technology, improved inputs and interventions targeted at women.

Analysis of over 10 years of agro-hydrological and agro-economic studies from southern African show that a different approach is required to interventions proposed. There are sustainability problems with free chemical fertiliser due to transport costs and ancillary costs. Furthermore, recent studies in Zimbabwe and Mozambique show that significant increases in yield can only be obtained when soil fertility management is combined with good crop husbandry, e.g. timely planting and weeding. Ongoing replenishment of fertility would be dependent on a continued free or subsidised fertiliser supply, and transport system. Increasing access to irrigation will help, but is not the only solution and cannot reach even a majority of farmers. It has been determined that short dryspells are often the major cause of low yields in sub-Saharan Africa. Soil-water conservation approaches, e.g. winter weeding and conservation tillage, can reduce risk and increase yield.

The following specific recommendations are made for urgent interventions to contribute sustainably to food security in southern Africa: (i) To increases access to fertiliser, consider development of strong input markets at end-user level. (ii) Intensification of technology transfer, focusing on capacity building for transfer of existing technologies and much closer collaboration between state and NGO sectors, agronomists and water engineers. (iii) Increasing the uptake of soil-water conservation methods, including conservation tillage and weeding, and supplementary irrigation to minimise adverse effects of dryspells, through investments in farmer training. (iv) Linking crop development strategies to livestock development practices and strategies. (v) Developing non-agro-based livelihood strategies in marginal lands.
\end{abstract}

(C) 2006 Elsevier Ltd. All rights reserved.

Keywords: Food security; Millennium development goals; Soil fertility; Soil-water conservation

\footnotetext{
${ }^{*}$ Corresponding author. Address: WaterNet, PO Box MP600, Mount Pleasant, Harare, Zimbabwe. Tel.: +263 4336725/838110; fax: +263 $4336740 / 838253$.

E-mail addresses: davidlove@science.uz.ac.zw, d.love@cgiar.org (D. Love), s.twomlow@cgiar.org (S. Twomlow),w.mupangwa@cgiar.org (W. Mupangwa), p.vanderzaag@unesco-ihe.org (P.van der Zaag), bgumbo@ eng.uz.ac.zw (B. Gumbo).
}

\section{The millennium development project and proposals for implementing the goals}

The first Millennium development goal (MDG) aims to eradicate extreme poverty and hunger. Target 2 of Goal 1 is to halve, between 1990 and 2015, the proportion of people who suffer from hunger. In order to achieve this, the Millennium Project proposes some initial, urgent measures 
and some longer term proposals. The interventions to be started immediately for quick results are referred to as the "quick-wins". In addressing food security (target 2), the Millennium Project proposes, as a quick-win, "a massive replenishment of soil nutrients for smallholder farmers on lands with nutrient depleted soils, through free or subsidised distribution of chemical fertilisers and agroforestry, no later than the end of 2006" (UN Millennium Project, 2005a). The emphasis on smallholder farmers is based on an assessment that of the 850 million people experiencing serious and chronic hunger, approximately $50 \%$ are smallholder farmers (FAO, 2004). For this reason, the Millennium Project recommendations on rural development and food security focus on improving the production and livelihoods of smallholder farmers. The Project's major concerns for agriculture are soil fertility, water resources management, access to improved varieties of crops and livestock and agricultural extension services (UN Millennium Project, 2005b).

Detailed intervention proposals from the Millennium Project include:

1. Investments in soil health: application of mineral fertiliser, agroforestry (use of trees to replenish soil fertility), erosion control, return of crop residues to the soil.

2. Appropriate irrigation technology, which the Millennium Project confusingly refers to as "small-scale water management": drip irrigation, wells, appropriate pumps and so on.

3. Improved inputs: improved varieties of crops, pastures, livestock, trees and fish.

4. Farm diversification to include higher value livestock and vegetables, once farm/household level food security has been achieved.

5. Extension services require strengthening, especially at village level, with upto date agricultural knowledge and participatory approaches to farmer training.

6. Agricultural research requires investment at the national level.

7. Interventions must be targeted to ensure empowerment of women farmers, including women extension officer recruitment, and promotion of women's property/tenure rights.

The MDG target to halve the proportion of people who suffer from hunger is extremely important in southern Africa, where food security has become increasingly problematic in the last half-century. Recurrent droughts and inconsistent national and regional policies fail to provide adequate support to large-scale and small-scale producers, leading to a net decline in agricultural production in the region. The poor performance of agriculture in Africa has been well documented. Per capita food production has not matched the growing population over the last 40 years (FAO, 2004). One hundred and eighty million of the world's 800 million food insecure people live in subSaharan Africa, surviving on less than 1 US dollar per day.
Therefore, implementation of the food security target of the millennium development goals is critical to the maintenance and improvement of livelihoods in southern Africa. However, as this paper will show, developing solutions at a global level does not always capture properly the needs and challenges of regional contexts. This is particularly important in considering the "quick-win" strategies proposed by the Millennium Project.

It is the hypothesis of this paper that whilst implementation of MDG target 2 is critical for southern Africa, the specific context of southern Africa requires a different approach (sometimes subtly different, sometimes dramatically different) to interventions proposed by the Millennium Project to work towards the MDGs. The specific hydrological and agro-hydrological conditions of southern Africa are particularly important. Accordingly, some modification of the approach is called for.

\section{Challenges to crop production in southern Africa}

\subsection{Context}

Africa's population is expected to reach 1.2 billion by the year 2020, double the 1995 figures. It estimated that at least $25 \%$ of the population will be undernourished and living in the dryland areas of sub-Saharan Africa, which already accommodate $70 \%$ of the world's poorest communities (Ryan and Spencer, 2001). Sub-Saharan Africa is the only region in the world where average food production per capita has been declining over the last 40 years. Yet agriculture continues to be the dominant economic activity, accounting for $70 \%$ of total employment, $40 \%$ of total exports and $34 \%$ of the GDP.

Despite the technological advances in agricultural research in recent years, poverty, food insecurity and malnutrition still remain major challenges in sub-Saharan Africa (Sanchez and Swaminathan, 2005), yet agriculture is the main economic activity in the region. Added to this are natural and human-induced conflicts, and low investment in long-term capacity building and research. Short-term land tenure arrangements implemented in some countries in the region sometimes do not encourage longterm investment on the land, especially where the tenure system is unclear or dynamic. That said, many improvements, especially in soil/water conservation, can be made on an annual rather than permanent basis, under any tenure system.

The most vulnerable groups are smallholder land users in the arid and semi arid lands. Smallholder farmers make up more than half the population at risk from hunger, and in southern Africa cultivate on poor soils and unreliable rainfall is the main source of water (Twomlow and Bruneau, 2000). Crop yields are low and failures are frequent (Scoones, 1996), with more than one million people in the Limpopo basin depending on food aid in 2003 (Love et al., 2004). In this context, agricultural production in southern Africa faces a number of challenges, each of 
which has implications for the Millennium Project's intervention proposals.

\subsection{Water}

Smallholder agriculture in southern Africa is largely rainfed, and thus risky, with recurrent droughts and dryspells. Potential evaporation exceeds rainfall for more than 6 months of the year. Rainfall is seasonal and highly variable. Annual rainfall for a single site can vary by up to $1000 \mathrm{~mm} / \mathrm{a}$ from year to year (Twomlow and Bruneau, 2000) - although a drought year may record less than $250 \mathrm{~mm} / \mathrm{a}$, such as the 2004-2005 season in southern Zimbabwe and Mozambique. By the end of the dry season, i.e. just before planting, the top $0.3 \mathrm{~m}$ of the soil horizon frequently holds negligible water content (Twomlow and Bruneau, 2000). Furthermore, a number of climate change models predict that southern Africa shall experience significantly reduced precipitation and runoff over the next 50 years (Arnell, 2003; Moyo et al., 2005a). These trends will result in further food shortages (Cane et al., 1994; Du du Toit and Prinsloo, 2001).

Frequently, the water yield from the developed surface water resource falls short of the demand, deficits being more evident during droughts (Nyabeze, 2004). Much of sub-Saharan Africa has, as a result of low conversion of rainfall to runoff, a precarious balance between available water resources and water demand (Mazvimavi, 2003). Furthermore, demand from more powerful sectors, such as urban areas and commercial farming, is rising. It has been suggested that the expansion of the SADC regional economy and especially the South African economy will necessitate water re-allocation from agriculture to urban areas and industry (Taigbenu et al., 2005). Even with such limitations, smallholder farmers have little access to blue water for irrigation (Love et al., 2004). This is partly due to a lack of investment targeting such developments, but also since, in some areas, there is a lack of suitable sites to establish further dams. Some catchments have been over-committed for quite some time (e.g. Kabel, 1984), meaning that additional surface water development is not possible, and others offer few sites where a possible river stretch for impoundment is coupled with suitable soils. Furthermore, most southern African governments face a chronic shortage of funding for capital investments such as dams.

\subsection{Soils}

Smallholder farmers generally farm on poor quality sandy or sandy loam soils (Twomlow and Bruneau, 2000). Frequently, such soils are infertile, deficient in nitrates, phosphates and sulphur (Burt et al., 2001). This is especially the case in those countries were colonial imbalances in land distribution have not been adequately adjusted. Even in countries where such attempts have been made, smallholder farmers are generally confined to the poorer soils. Rising populations have placed an increasing burden on the soils farmed by smallholder farmers: in the last half-century in southern Africa the populations have increased dramatically, but the availability of land to smallholder farmers has not increased significantly in most countries. Thus a higher population is depending on the same area of semi-fertile land (Moyo, 2004).

Fertiliser usage is low in southern Africa, compared for example to India: $28 \mathrm{~kg} / \mathrm{ha}$ compared to $62 \mathrm{~kg} / \mathrm{ha}$ (Twomlow et al., 1999). Due to lack of investment in soil fertility amendments to cope with declining yields, farmers have extensified their cropping area. As soil fertility declined, farmers have maintained household food requirements by increasing the cropped area to compensate for lower yields.

\subsection{Economics and livelihood strategies}

The question of livelihood strategies is not addressed adequately in the MDGs. Rural families livelihood strategies are not necessarily geared directly to food production, many household have diverse coping strategies to ensure some degree of sustainable livelihoods. Livestock (which are not generally a food source but a strategic financial asset) are valued ahead of crop production. For example, farmers in many southern African countries prefer to feed crop residues to their cattle than to mulch or plough in the residues. This is despite the well-proven benefits in terms of soil fertility improvement, and also increased infiltration from precipitation (Bennie and Hensley, 2001).

Studies have shown that poverty in southern Africa presents a greater driver to food insecurity than actual food production. It has been suggested that access to food can be a greater problem for households than absolute food availability (Misselhorn, 2005). This can be partly due to few smallholder farmers subsisting entirely on their own production, and must still sell some produce to buy some of their food. Since it is well established that world food production is sufficient, but distribution inadequate (e.g. Myers, 1985), it is not logical to resolve food security problems by focussing solely on increasing production.

\subsection{Political will}

The extent to which agricultural reform and revitalisation of agricultural practice (or the "green revolution") is a priority in southern Africa is limited, compared, for example, to prioritisation of land reform (changes in land distribution and tenure) (Moyo, 2004) or the commercialisation of agriculture.

\section{Adapting and operationalising the MDGs for food security in southern Africa}

\subsection{Fertiliser}

The quick-win proposal on mineral fertiliser is especially difficult. Accelerating and increasing fertiliser use does not 
deal with the underlying causes of declining soil fertility in southern Africa. Thus, while an urgent and massive investment in mineral fertiliser will have a short-term impact; it is unlikely to make any impact on food security in the medium term. It should be realised that a massive investment in mineral fertiliser does not address long-term food security problems: there is no guarantee that such an investment would translate into a sustainable improvement in soil health. Ongoing replenishment of fertility would be dependent on a continued, guaranteed free or subsidised supply, transport system and so on.

The low rate of fertiliser application in southern Africa reflects the much higher end user price of fertiliser in Africa. This is often due to transport and import costs, especially in landlocked countries. Smallholder farmers are generally living distant from the major urban centres of their countries, increasing transport costs for them. This leads to a vicious circle at the smallholder level where current recommendations are inappropriate: few farmers have had positive experiences of heavy fertiliser use, thus there is little demand, and thus rural tradestores do not stock much variety of fertiliser. Occasional free fertiliser handouts, by government or NGOs, tend to destabilise the small local markets, in countries where fertiliser production is done by private companies. Such interventions thus provide short-term benefits but medium-term problems. These ancillary costs will remain to limit smallholder farmers in southern Africa, even if the original procurement of fertiliser is free or heavily subsidised internationally.

Fertiliser is insufficient in itself to produce a major change in the food security situation. Major increases in yield can only be obtained when soil fertility management is combined with soil-water conservation practices such as timely planting and weeding, thus reducing periods of potential moisture stress/competition (Twomlow et al., 1999). For these reasons, massive investment in mineral fertiliser will not produce a "quick win" unless it is integrated with transport and other interventions.

\subsection{Water and irrigation}

Irrigation schemes have a role to play, and smallholder irrigation schemes can become a critical common property resource (Samakande et al., 2004). However, such schemes also tend to over-apply water (Senzanje et al., 2003), for a variety of reasons such as design and pricing policies. Water allocation between farmers is not always equitable or efficient, especially during drought years (Munamati et al., 2005). Poor water management on such schemes also leads to reduced yields (Samakande et al., 2004). Furthermore, access to irrigation water for the smallholder farmer remains limited. The Millennium Project recognises the limitations of large-scale irrigation for food security in Africa and urges the use of appropriate irrigation technology such as low-cost drip kits. This can allow for greater access to irrigation, since the water and energy requirements are lower than conventional irrigation (Chigerwe et al., 2004). It can also allow for irrigation at smallholder household level, rather than smallholder scheme level. Drip technology on its own tends to improve water use efficiency, but sometimes does not increase yield (Maisiri et al., 2005). A recent study showed that only $2 \%$ of the beneficiaries had used the kit to produce the expected five harvests over 2 years, owing to problems related to water shortage and also pests and diseases. Conflicts between beneficiaries and water point committees or other water users developed in some areas especially during the dry season (Moyo et al., 2005b). Thus the implementation of small-scale irrigation has to be done in a manner to address these challenges.

As an alternative to permanent irrigation, yields can be improved by short-term supplementary irrigation during dryspells (Savenije, 1998, 1999; Nyamudeza, 1999; Falkenmark and Rockström, 2003; Rockström et al., 2003). As an alternative to dams, use can be made of rainwater harvesting technologies (Motsi et al., 2004) or accessing of alluvial aquifers (Dahlin and Owen, 1998; Moyce et al., 2005).

However, small-scale irrigation as promoted by the millennium project (e.g. Sanchez and Swaminathan, 2005) is not the only solution. Irrigation schemes can never benefit more than a small minority of farmers in a district, since there may not be sufficient water resources, and an investment of an order of magnitude way beyond that proposed by the millennium project would be required. To improve yield and livelihoods for a larger proportion of smallholder farmers, an approach of integrated soil and water management is needed for dryspell and drought mitigation. Short dryspells - not necessarily water scarcity measured at an annual scale - are often the major cause of low yields and loss of food security (Rockström et al., 2003). Improvements can be achieved through agricultural interventions in dryland farming (Twomlow et al., 1999). Some in field water management technologies, such as tied ridges, have proven effective at reducing runoff, thus increasing infiltration and water access to the crops (Heinrich, 2001; Motsi et al., 2004) - although uptake is variable (Twomlow et al., 1999). Conservation tillage approaches, especially where they are adapted for use with animal traction, have proven very effective in increasing water availability to crops and decreasing land degradation (Kaumbotho and Mwenya, 2000; Mupangwa et al., 2005; Twomlow et al., 1999).

Effective weeding also increases both in-field water availability and crop yield. Biomass can be increased by a factor of four and water use efficiency $(\mathrm{kg} / \mathrm{mm})$ by a factor of five, for well weeded maize compared to an unweeded control (Twomlow et al., 1999). Weed growth influences negatively the availability of water in the soil profile, especially during dryspells (Twomlow and Bruneau, 2000). It is not only rainfed farming, but also smallholder irrigation schemes that can benefit from improved soil-water management (Samakande et al., 2004).

Often, the problem is not physical scarcity of water, but rather the lack of integrated management approaches 
(linking crops, soil, water and climate), human and financial capacities and weak institutional arrangements. The new water governance in the Limpopo Basin countries enshrines principles of equity and user participation in decision-making (Love et al., 2004). Catchment institutions provide a possibility for progressive and sustainable, stakeholder-based water management (Manzungu and Mabiza, 2004; Savenije and van der Zaag, 2000; Van der Zaag and Savenije, 2000). However, penetration remains problematic: smallholder farmers tend to have very little voice, while large water users dominate (Love et al., 2004; Nare et al., 2005; Van der Zaag, 2005).

\subsection{Other interventions}

Access to improved varieties for smallholder farmers is often limited, and faces many of the same limiting factors as fertiliser distribution. Furthermore, many classic "green revolution" improved varieties are not drought resistant and produce the expected high yields only when free of water stress. Finally, if crop management is not improved at the same time as new varieties are adopted, the farmer will never see the real yield potential.

A significant level of farm diversification already exists in southern Africa, often focusing on livestock, as has been discussed under livelihood strategies above. However, additional farm diversification requires developments of a market for the new produce, and a transport strategy to ensure that the value added in the new produce is not lost to transporters.

Women farmers actually spend substantial amounts of their time and labour on activities not directly connected with agricultural production. Thus developing improved efficiencies of transport and cooking fuels, and improving ease of access to water for domestic purposes would release a large proportion of the woman farmer's labour for her to invest on her farm.

In many countries in southern Africa, what is needed is not retraining of extension staff - much of the most recent knowledge is well known - but resources for expansion of service work and improvement of the conditions of staff to ensure capacity retention.

\section{The way forward}

The agricultural, climatic, sociocultural and economic context of southern Africa presents challenges that require modifications and alternatives to the interventions proposed by the Millennium Project to work towards the MDGs. Specific recommendations are now made for urgent interventions in agriculture in southern Africa, in order to contribute to food security, as an alternative to the Millennium Project's fertiliser subsidy proposal. Firstly, interventions in inputs (seed and fertiliser) should not be simple subsidies, but should be sustainable investments targeted at either end-user level or at the transport and marketing system. Upgrading the distribution system for inputs will have a longer term and more sustainable impact than free distribution of fertiliser for one or two seasons. The constraint posed by transport is clear, since it has been cited as a major constraint to application of manure, which is readily available (Rohrbach, 2001). Developing the market for inputs, especially for sale of small quantities of inputs, will allow a contribution from the small-scale enterprise sector (Sanders, 2002), and facilitate the development of a sustainable fertiliser distribution network in smallholder farming areas.

Increasing the application and uptake of soil-water conservation methods, including conservation tillage and weeding, is needed in dryland farming and in supplementary irrigation. The interventions should be carried out mainly through intensive investments in farmer training, by collaborating government services (both agricultural extension and state water authorities) and NGOs. The approach must be participatory, to determine what techniques smallholder farmers have themselves found effective in the drier years, and involve farmers in the moitoring and evaluation (Gupta, 2002). This has to be the priority area in extension work, as water management is often the limiting factor in yield and this proposed intervention is more practical and affordable than a massive expansion of irrigation. The amount of funding that can be mobilised internationally for MDG interventions would therefore be better targeted at on-farm water management than new irrigation schemes. The latter would, for the same amount of funding, benefit far fewer farmers and make a lesser contribution to food security. This intervention is not a "new story", but is deserving of a higher priority than has been indicated by the Millennium Project, since it can benefit a greater number of food insecure people than the proposed fertiliser subsidy.

Water resources planning and evaluation is required before and during implementing irrigation interventions, whether these are conventional irrigation schemes, drip kit distribution or supplementary irrigation. It must be ascertained that the water supply assumed for an irrigation project is sufficient, sustainable and acceptable to the community, especially to non-beneficiaries. It is essential that the agriculturalists and the water engineers should engage with each other; preferably at the local government and water management area levels. Proper planning of this kind is likely to decreased risk of conflicts between water users after implementing the irrigation intervention, and decreased risk of intervention failure to lack of water supply.

Alternative livelihood strategies need developing and promoting, especially in the semi-arid to arid areas. One adaptation is to link crop development strategies to livestock development. However, for as long as rural populations increase, and expect to engage in agriculture as their major productive activity, without an increase in land allocation to smallholder farmers, soil fertility and food security will continue to decline, as land is over-utilised (Twomlow and Bruneau, 2000). Accordingly, investment 
should be made in developing non-agro-based livelihood strategies in marginal lands, including the harvesting of indigenous rangeland products, such as the mopani worm, wildlife management and so on. Given the extent to which poverty, rather than food production, influences food security in southern Africa (Misselhorn, 2005), this could have a major impact.

Finally, consideration should be given to investments in drivers for produce marketing, including the provision of information on prices over radio and other media. Such a system has been implemented in Zimbabwe for many years, and allows farmers to choose where to sell their produce before leaving home for the city markets.

\section{Acknowledgements}

This paper is a contribution to WaterNet Challenge Program Project 17 "Integrated Water Resource Management for Improved Rural Livelihoods: Managing risk, mitigating drought and improving water productivity in the water scarce Limpopo Basin", funded through the CGIAR Challenge Program on Water and Food. The opinions and results presented in this paper are those of the authors and do not necessarily represent the donors or participating institutions. The cooperation of the Department of Agricultural Research and Extension Services in the Ministry of Agriculture and Rural Development (Matabeleland South Province) has been essential and is gratefully acknowledged. Comments by Hubert Savenije and an anonymous reviewer improved the quality of this paper.

\section{References}

Arnell, N., 2003. Effects of IPCC SRES emissions scenarios on river runoff: a global perspective. Hydrology and Earth System Sciences 7, 619-641.

Bennie, A.T.P., Hensley, M., 2001. Maximizing precipitation utilization in dryland agriculture in South Africa - a review. Journal of Hydrology 241, 124-139.

Burt, R., Wilson, M.A., Kanyanda, C.W., Spurway, J.K.R., Metzler, J.D., 2001. Properties and effects of management on selected granitic soils in Zimbabwe. Geoderma 101, 119-141.

Cane, M.A., Eshel, G., Buckland, R.W., 1994. Forecasting Zimbabwean maize yield using eastern equatorial Pacific seas surface temperatures. Nature 370, 204-205.

Chigerwe, J., Manjengwa, N., van der Zaag, P., Zhakata, W., Rockström, J., 2004. Low head drip irrigation kits and treadle pumps for smallholder farmers in Zimbabwe: a technical evaluation based on laboratory tests. Physics and Chemistry of the Earth 29, 1049-1059.

Dahlin, T., Owen, R.J.S., 1998. Geophysical investigation of alluvial aquifers in Zimbabwe. In: Proceedings of the Fourth EEGS Meeting, Barcelona, Spain.

Du du Toit, A.S., Prinsloo, M.A., 2001. El Niňo-southern oscillation effects on maize production in South Africa: a preliminary study. In: Impact of El Nino and Climate Variability on Agriculture, vol. 63. ASA Special Publication, pp. 77-86.

Falkenmark, M., Rockström, J., 2003. Balancing Water for Man and Nature: The New Approach in Ecohydrology. EarthScan, London.

FAO, 2004. The State of Food Insecurity in the World: Monitoring progress towards the World Food Summit and Millennium Develop- ment Goals. Food and Agricultural Organisation of the United Nations, Rome.

Gupta, S.C., 2002. On-farm technology transfer: experience of ICRISATNigeria. In: ICRISAT and IFAD. 2002. Improving Income and Food Supply in the Sahel - On-farm Testing of Sorghum and Pearl Millet Technologies: Summary Proceedings of the Stakeholders' Workshop to Plan and Implement the IFAD Project, 24-26 February 1999, ICRISAT, Sadoré, Niger. International Crops Research Institute for the Semi-Arid Tropics, Bamako, Mali and International Fund for Agricultural Development, Rome, Italy. Available from http:// www.icrisat.org/.

Heinrich, G., 2001. Improving productivity and incomes for small-scale farmers in the semi-arid areas of Zimbabwe: on-farm participatory research in Gwanda. In: Twomlow, S.J., Ncube, B. (Eds.), Improving Soil Management Options for Women Farmers in Malawi and Zimbabwe: Proceedings of a Collaborators' Workshop on the DFID-supported Project "Will Women Farmers Invest in Improving their Soil Fertility Management? Participatory Experimentation in a Risky Environment", ICRISAT Bulawayo, Zimbabwe. Available from http://www.icrisat.org/.

Kabel, T.C., 1984. An Assessment of Surface Water Resources of Zimbabwe and Guidelines for Development Planning. Department of Water Development, Government of Zimbabwe, Harare.

Kaumbotho, P.G., Mwenya, E., 2000. Preserving the environment through conservation tillage with animal traction. In: Kaumbotho, P.G., Pearson, R.A., Simalenga, T.A. (Eds.), Proceedings of the Workshop of the Animal Traction Network for Eastern and Southern Africa ATNESA, Mpumalanga, South Africa, 20-24 September 1999.

Love, D., Jonker, L., Rockström J., van der Zaag, P., Twomlow, S., 2004. The challenge of integrated water resource management for improved rural livelihoods in the Limpopo basin - an introduction to WaterNet's first network research program. In: Abstract Volume, Fifth WaterNet-WARFSA Symposium, Windhoek, Namibia, pp. 106-107.

Maisiri, N., Rockström, J., Senzanje, A., Twomlow, S.J., 2005. An onfarm evaluation of the effects of low cost drip irrigation on water and crop productivity, compared to conventional surface irrigation system. Physics and Chemistry of the Earth 30, 783-791.

Manzungu, E., Mabiza, C., 2004. Status of water governance in urban areas in Zimbabwe: some preliminary observations from the city of Harare. Physics and Chemistry of the Earth 29, 1167-1172.

Mazvimavi, D., 2003. Estimation of flow characteristics of ungauged catchments: case study in Zimbabwe. PhD dissertation. Wageningen University and International Institute for Geo-Information Science and Earth Observation, Delft.

Misselhorn, A.A., 2005. What drives food insecurity in southern Africa? A meta-analysis of household economy studies. Global Environmental Change 15, 33-43.

Motsi, K.E., Chuma, E., Mukamuri, B.B., 2004. Rainwater harvesting for sustainable agriculture in communal lands of Zimbabwe. Physics and Chemistry of the Earth 29, 1069-1073.

Moyce, W., Mangeya, P., Love, D., Owen, R., 2005. Alluvial aquifers in the Mzingwane Catchment: their distribution, properties, current usage and potential expansion and risk. In: Abstract Volume, Sixth WaterNet-WARFSA-GWP Symposium, Swaziland, November 2005, p. 122.

Moyo, S., 2004. Land allocation, beneficiaries and agrarian structure. National Stakeholders' Dialogue on Land and Agrarian Reform, Harare, July.

Moyo, B., Madamombe, E., Love, D., 2005a. A model for reservoir yield under climate change scenarios for the water-stressed City of Bulawayo, Zimbabwe. In: Abstract Volume, Sixth WaterNet-WARFSA-GWP Symposium, Swaziland, November 2005, p. 38.

Moyo, R., Love, D., Mul, M., Twomlow, S., Mupangwa, W., 2005b. Impact and sustainability of drip irrigation kits in the semi-arid Lower Mzingwane Subcatchment, Limpopo Basin, Zimbabwe. In: Sixth WaterNet-WARFSA-GWP Symposium, Swaziland, November 2005, p. 115.

Munamati, M., Mhizha, A., Sithole, P., 2005. Cultivating livelihoods: an assessment of water allocation and management practices in 
small-scale irrigation schemes - case studies in Mzingwane Catchment. In: Abstract Volume, Sixth WaterNet-WARFSA-GWP Symposium, Swaziland, November 2005, p. 120.

Mupangwa, W., Love, D., Twomlow, S., 2005. Soil-water conservation and other rainwater harvesting strategies in the semi-arid Mzingwane Catchments, Limpopo Basin, Zimbabwe. In: Abstract Volume, Sixth WaterNet-WARFSA-GWP Symposium, Swaziland, November 2005, p. 155.

Myers, N. (Ed.), 1985. The Gaia Atlas of Planet Management. Pan Books, London.

Nare, L., Love, D., Hoko, Z., 2005. Involvement of stakeholders in the water quality monitoring and surveillance system: the case of Mzingwane Catchment. In: Abstract Volume, Sixth WaterNet-WARFSA-GWP Symposium, Swaziland, November 2005, p. 12.

Nyabeze, W.R., 2004. Estimating and interpreting hydrological drought indices using a selected catchment in Zimbabwe. Physics and Chemistry of the Earth 29, 1173-1180.

Nyamudeza, P., 1999. Agronomic practices for the low rainfall regions of Zimbabwe. In: Manzungu, E., Senzanje, A., van der Zaag, P. (Eds.), Water for Agriculture in Zimbabwe. University of Zimbabwe Press, Harare.

Rockström, J., Barron, J., Fox, P., 2003. Water productivity in rain-fed agriculture: challenges and opportunities for smallholder farmers in drought-prone tropical agroecosystems. In: Kijne, J.W., Barker, R., Molden, D. (Eds.), Water Productivity in Agriculture: Limits and Opportunities for Improvement. CAB Internationals, London.

Rohrbach, D.D., 2001. Zimbabwe baseline: crop management options and investment priorities in Tsholotsho. In: Twomlow, S.J., Ncube, B (Eds.), Improving Soil Management Options for Women Farmers in Malawi and Zimbabwe: Proceedings of a Collaborators' Workshop on the DFID-supported Project "Will Women Farmers Invest in Improving their Soil Fertility Management? Participatory Experimentation in a Risky Environment", ICRISAT Bulawayo, Zimbabwe. Available from http://www.icrisat.org/.

Ryan, J.G., Spencer, D.C., 2001. Future challenges and opportunities for agricultural $\mathrm{R} \& \mathrm{~S}$ in the semi-arid tropics. International Crops Research Institute ICRISAT, Patancheru, India.

Samakande, I., Senzanje, A., Manzungu, E., 2004. Sustainable water management in smallholder irrigation schemes: understanding the impact of field water management on maize productivity on two irrigation schemes in Zimbabwe. Physics and Chemistry of the Earth 29, 1075-1081.

Sanchez, P.A., Swaminathan, M.S., 2005. Hunger in Africa: the link between unhealthy people and unhealthy soils. Lancet $365,442-444$.

Sanders, J., 2002. Input and output markets and the introduction of sorghum-millet technologies. In: ICRISAT and IFAD. 2002. Improv- ing Income and Food Supply in the Sahel - On-farm Testing of Sorghum and Pearl Millet Technologies: Summary Proceedings of the Stakeholders' Workshop to Plan and Implement the IFAD Project, 24-26 February 1999, ICRISAT, Sadoré, Niger. International Crops Research Institute for the Semi-Arid Tropics, Bamako, Mali and International Fund for Agricultural Development, Rome, Italy. Available from http://www.icrisat.org/.

Savenije, H.H.G., 1998. "How do we feed a growing world population in a situation of water scarcity?". In: Eighth Stockholm Symposium "Water - The Key to Socio-economic Development and Quality of Life", SIWI, Stockholm, pp. 49-58.

Savenije, H.H.G., 1999. "The role of Green Water in food production in sub-Saharan Africa". In: Background Paper for the FAO InternetEmail Conference on "Water for Food in sub-Saharan Africa", FAO, Rome. Available from http://www.fao.org/ag/agl/aglw/webpub/ greenwat.htm.

Savenije, H.H.G., van der Zaag, P., 2000. Conceptual framework for the management of shared river basins with special reference to the SADC and EU. Water Policy 2, 9-45.

Scoones, I., 1996. Hazards and Opportunities; Farming Livelihoods in Dryland Africa: Lessons from Zimbabwe. Zed Books, London.

Senzanje, A., Samakande, I., Chidenga, E., Mugutso, D., 2003. Field irrigation practices and the performance of smallholder irrigation in Zimbabwe: case studies from Chakowa and Mpudzi irrigation schemes. Journal of Agricultural Technology 5, 76-89.

Taigbenu, A.E., Ncube, M., Boroto R.J., 2005. Resources management in agriculture: convergence of needs and opportunities. In: 12th South African National Hydrology Symposium, Midrand, South Africa, September 2005, pp. 1-10.

Twomlow, S., Bruneau, P., 2000. Semi-arid soil water regimes in Zimbabwe. Geoderma 95, 33-51.

Twomlow, S., Riches, C., O’Neill, D., Brookes, P., Ellis-Jones, J., 1999. Sustainable dryland smallholder farming in sub-Saharan Africa. Annals of Arid Zone 38, 93-135.

UN Millennium Project, 2005a. Investing in Development: A Practical Plan to Achieve the Millennium Development Goals, Earthscan, New York.

UN Millennium Project, 2005b. Halving Hunger: It can be Done. Report of the Task Force on Hunger, Earthscan, New York.

Van der Zaag, P., 2005. Integrated Water Resources Management: Relevant concept or irrelevant buzzword? A capacity building and research agenda for Southern Africa. Physics and Chemistry of the Earth 30, 867-871.

Van der Zaag, P., Savenije, H.H.G., 2000. Towards improved management of shared river basins: lessons from the Maseru Conference. Water Policy 2, 47-63. 